$\xi=-1$

\title{
Region Building Complex Social and Economic Security Threats
}

\author{
Hanna Kozachenko ${ }^{1}$, Svitlana Onychshenko ${ }^{2 *}$, Oleksandra Masliy ${ }^{3}$ \\ ${ }^{1}$ Poltava National Technical Yuri Kondratyuk University, Ukraine \\ ${ }^{2}$ Poltava National Technical Yuri Kondratyuk University, Ukraine \\ ${ }^{3}$ Poltava National Technical Yuri Kondratyuk University, Ukraine \\ *Corresponding Author E-Mail: S07onyshchenko@Gmail.Com
}

\begin{abstract}
The basic threats of region building complex social and economic security were investigated. From the standpoint of protective approach established negative factors, which provoke the appearance, threats and significantly reduce the level of region building complex social and economic security. It was found real threats to region building complex economic security. On the basis of multi-material division threats to region building complex economic security were systematized. It was underlined that the proposed division of threats can solve a set of problems in ensuring region building complex economic security.
\end{abstract}

Keywords: building complex, economic security, grouping, protective approach, region, threats.

\section{Introduction}

The building complex of any country is one of the most capitalintensive and differentiated production systems, its performance has a decisive influence on the pace, scale, production location, performance and enterprises efficiency with other types of activities, regional and national economy as a whole. Particular emphasis should be put on the role of the building complex in improving the socio-economic status of the regions and recognizing its leading role in their socio-economic development.

The building complex is a complex inter-sectoral industrial and economic system [1], whose elements carry out design and survey works, building materials production, products and structures, capital construction, buildings and structures modernization and renovation (industrial, transport and civilian) [2] .

Construction is a specific industry. On the one hand, for the national economy, it is economic growth factor. According to that role, industrial construction is experiencing an acceleration or slowdown in the other industrial spheres development and therefore considered national economy dynamics indicator. On the other hand, civil construction reflects socio-economic development of the country and its regions results. At the national and regional levels, building complex production duality and consumer qualities reveal itself in a very complex and yet poorly understood economic mechanism of its relationship with other sectors of the economy.

Building complex functioning, as well as any other production system, is effective if there are appropriate conditions, and the most important today is economic security.

\section{Main Body}

Enterprises economic security, production systems, industries and the region research has been substantially updated in the last decade. And today we can already speak of the creation of an exploratory basis of economic securitiology, the position is shaped by its epistemological field (preconditions for the economic security phenomenon emergence, its nature, patterns of origin, types, approaches to study, etc.).

Building complex enterprises economic security is the subject of consideration in scientific publications (for example, $[3,4,5,6]$ ). Their analysis results and a significant number of other scientific works have shown that their authors focus on construction enterprises activity threats. Threats to the construction companies' activity are, of course, an important aspect of their economic security, but their research should be based on the economic security exploratory fundamentals provisions.

Previous research analysis of the construction enterprises economic security has also shown that they are practically outside the ontological and epistemological aspects of economic security. Such studies to a large extent do not derive from the general preconditions for the knowledge of economic security, which are already established in these aspects: the revealed nature of economic security, the status (or attribute) of this concept (state of the enterprise, its need or condition of activity), the chosen approach to its study (evaluation and provision) (protective, resource, activity or harmonization). Neglecting of the echelon basis provisions economic security does not enable constructing the ratio of knowledge and reality in the necessary way, to develop substantive economic security, most importantly, to identify the conditions of reliability and truth of knowledge, to ensure economic security praxeological context concepts authenticity.

The purpose of the article is to consider threats to the region enterprises building complex economic security, based on the economic security provision.

Building complex economic security is recognized as its enterprises activity and development condition, which presence is the result of the organizational and legal and economic nature of the state, the region and enterprises themselves interconnected targeted actions.

One of the main concepts of enterprises building complex economic security study is epistemological contextualism [7], the concept content is disclosed accordingly. Building complex economic security is considered from the standpoint of a protective 
approach, where imperative concepts are "threat", "protection", "security" [8, p. 27-28]

The building complex enterprises economic security as its enterprises activity and development condition from the standpoint of a protective approach is considered as such an environment where an enterprise, together with state institutions, with the securityproviding activity of the region, using its own resources, is capable of detecting, avoiding, mitigating or overcoming the consequences the realization of the threats that create processes, phenomena, materialized interests and goals of the subjects of the external environment. The definition is an adaptation of the general definition of the concept "economic security of the enterprise", provided in [8, p. 27-28], taking into account selected research construction industry concepts and features.

Based on the presented research concepts, it is fully justified to focus on the threats to the region building complex economic security.

The threat to region building complex economic security system should be considered as various processes, certain phenomena in the society and the economy of the state, which under certain conditions can cause negative forced changes in the enterprises activities complex, for its elimination, to overcome their consequences or to adapt to them requires effort, time and resources of the complex enterprises. Such negative changes reduce region building complex compliance with the requirements, challenges and realities of the time, its stability, the ability to fulfill its purpose and, ultimately, the performance of the operation.

A distinctive threats feature to region building complex economic security is their joint implementation, separate stages of the threats development non-coincidence (the threat is considered from the standpoint of the process approach). This process cannot be restricted.

Typically, the threats emergence is a long process, where under the certain conditions (phenomena, processes) acting as catalysts or inhibitors, can accelerate, slow down or attenuate.

Threats to the enterprises economic security with any kind of activity are of multicutual, multifactorial nature [9]. Each of the threats has special preconditions of occurrence, own manifestation character and degree of influence on region building complex economic security level.

Threats to region building complex economic security in the first approximation are divided into the following groups:

General nature threats of a (arise for enterprises with any kind of activity);

Regional nature threats (occur for enterprises located in a specific region);

The threats belonging to each of these groups arise and can be realized at the same time, they are interrelated and interdependent by the common destructive factors that are their sources. Therefore, their research should be carried out using their occurrence and manifestation chronopolitical patterns (Fig. 1 [9]).

As to the region building complex economic security threats, the following should be noted.

Threats to region building complex economic security are considered as only those processes and phenomena that completely destroy the object (resources access full restriction, money circulation disruption, provoking economic system destruction of the, etc.), or cause significant damage to it. Difficulties arise when assigning the latter to threats quantity, because in a competitive environment, the risk is regional economic system functioning integral part. At the same time, those phenomena which in the short term can be attributed to threats, in the long run may be an incentive for the building complex economic development, innovation activity growth, more rational energy policy, and so on.

To study region building complex economic security threats it is expedient to group them into the most significant features. The grouping enables identifying different type's threats, applying in their study uniform tools.

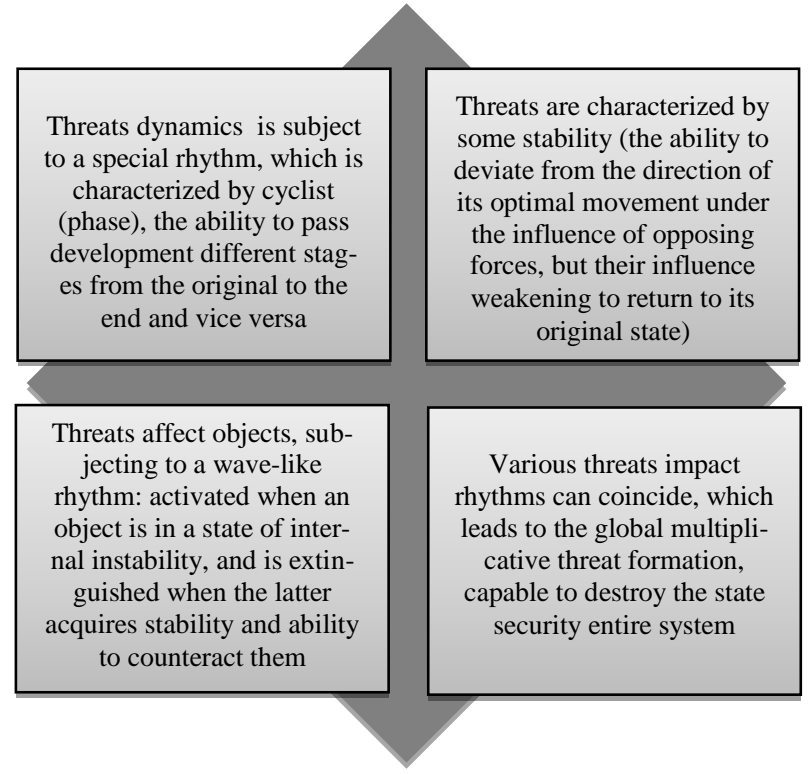

Fig. 1: Occurrence and manifestation threats patterns to the any object economic security

Internal and external threats interconnection and interdependence conditions, external threats growth determines region building complex economic security (for example, construction industry regional regulation ineffectiveness in decentralization conditions generates external threats appearance and implementation). In modern conditions, internal threats destructive impact to region building complex socio-economic security is compounded by external challenges and threats. Therefore, an integrated approach to their identification, elimination, neutralization or mitigation of the implementation consequences is necessary.

Modern concepts perspective ensuring various objects weight gains economic security threats division to real and potential. Such a division is carried out according to the occurrence conditions probability (risk degree) while security object economic interests may be infringed.

At a potential threat there is a probability of damage (damage) to building complex region enterprises. But the potential threat with some probability (for certain conditions) can be realized or not. Therefore, building complex region enterprises may try to reverse the threat, counteract its implementation or prepare for it (for example, by developing measures to mitigate the threat effect).

The real threat is high implementation probability, which is difficult to distract it, it is able to cause serious damage (damage) to region enterprises building complex its interests, financial resources, concrete objects (for example, reputation).

A potential threat can be averted, while in relation to the real threat it is necessary to prepare for its realization in order to minimize its destructive influence on the region building complex economic security and prevent its transformation into a potential or even real danger.

Fig. 2 provides a list of major real threats to region building complex economic security (threats are highlighted by implementation). These threats belong to the internal ones, they are conditioned by region building complex state and features as a security object, construction industry cyclical development, arise as a result of long-term destructive trends gradual accumulation in it.

Realizing threats probability to the region building complex economic security, conditioned by construction activity peculiarities, implementation consequences, is greatly enhanced in conditions where national and regional character threats implementation is highly probable. Thus, it refers to all types' threats implementation complementary nature.

Threats probability to the region building complex economic security is constantly changing due to the regional economy functioning dynamic conditions and the national economic system as a whole. Usually the decisive influence on regions building complex socio-economic security state is caused by internal threats, but in 
create a system for early detection of threats to region building complex economic security, which is the basis for its provision.

\section{References}

[1] Smirnova OP (2016), Methodology of studying the economic security of the construction industry in Russia at the present stage. Internet-journal 'Science', Vol.8, No.3, available online: http://naukovedenie.ru/PDF/140EVN316.pdf.

[2] Building complex of Ukraine. [online] Available at: <https://we.org.ua/ekonomika/budivelnyj-kompleks/> [Accessed 17 December 2017]

[3] Melnikov AB, Shnmishchikova IV \& Markova SV (2011), Features of providing economic safety at the enterprises of the construction industry. Theory and practice of social development 1, 245-250.

[4] Pushkar TA \& Dyachenko KS (2013), Peculiarities of economic safety of enterprises of the construction industry. Problems and prospects of entrepreneurship development 2, 134-139.

[5] Andrienko VM (2012), Specific types of threats and peculiarities of organization of maintenance of economic safety of construction enterprises. Effective economy 12, available online: http://www.economy.nayka.com.ua/?op=1\&z=2368.

[6] Karpova KV (2015), Analysis of threats to the economic security of construction enterprises. Construction production 58, 18-20.

[7] Karimov AR (2013), Contextualism, skepticism, pragmatics. Historical, philosophical, political and legal sciences, culturology and art history. Questions of theory and practice 6 (32), 71-76.

[8] Ilyashenko OV, Mechanisms of the system of economic security of the enterprise, Kharkiv, Machulin, (2016), 504 p.

[9] Smelyantsev AP, The problem of threats to the interests of Ukraine's security (socio-philosophical analysis). Author's abstract dis Cand. Philosophy Sciences: 09.00.03., Kharkiv, Military Uvesity. Kh. (2001), 18 p.

[10] Kozachenko GV \& Pogorelov YuS, Risk, threat, danger in economic safetyology: causal connection. Economic security: the state, the region, IV All-Ukrainian sciences Internet Conf. with international participation (10 December, 2017 - 25 January, 2018), Poltava, Poltava National Technical Yuri Kondratyuk University, (2018), 24-27.

[11] The President of Ukraine (2015, 12 January). About the strategy of steady development 'Ukraine - 2020' (Working Paper No 5/2015). Retrieved from http://zakon5.rada.gov.ua/laws/show/ 5/2015

[12] The Cabinet of Ministers of Ukraine (2014, 6 August). On the establishment of state social standards in the field of housing and communal services (Working Paper No. 409). Retrieved from http://zakon2.rada.gov.ua/laws/show/409-2014-п

[13] Varnaliy Z., Onishchenko S., Masliy A. 2016. Preventing threats as a precondition to increase the level of Economic Security of the State / Scientific Journal «ScienceRise»,7/1(24), pp.41-46. doi: 10.15587/2313-8416.2016.74409

[14] Tkach, V.O. (2010). Economic security of the region as a constituent of the state economic security. Visnyk Dnipropetrovs'koho universytetu (Ser. «Ekonomika»), 4(1), 113-120 